\title{
Penerapan Model Pembelajaran Inkuiri Terbimbing Sebagai Upaya Meningkatkan Prestasi Belajar IPA Siswa
}

\author{
Ni Made Warsiki*
}

SMP Negeri 2 Singaraja

A R T I C L E I N F O

Article history:

Received 20 February

2019

Received in revised form

10 March 2019

Accepted 24 April 2019

Available online 20 May

2019

Kata Kunci:

Model Pembelajaran

Inkuiry Terbimbing,

Prestasi Belajar

Keywords:

Guided Inkuiry Learning

Model, Learning

Achievemen

\begin{abstract}
A B S T R A K
Tujuan penelitian tindakan kelas ini adalah untuk meningkatkan aktivitas dan prestasi belajar siswa dalam pembelajaran IPA melalui Penerapan Model Pembelajaran Inkuiri Terbimbing. Data penelitian dikumpulkan melalui observasi aktivitas siswa dalam proses pembelajaran dan tes prestasi belajar, yang selanjutnya dianalisis dengan menggunakan metode deskriptif kualitatif unruk data aktivitas siswa dalam proses pembelajaran, serta deskriptif kuantitatif untuk data hassil test prestasi belajar. Data disajikan dalam bentuk rata-rata dan prosesntase ketuntasan belajar. Penerapan model pembelajaran Inkuiri Termimbing secara positif dapat merubah kualitias pembelajaran IPA, dibuktikan dengan adanya perkembangan prestasi belajar. Pada awalnya rata-rata prestasi belajar siswa hanya 72,48 dengan ketuntasan belajar hanya $44,74 \%$, selanjutnya setelah pelaksanaan Siklus I ratarata prestasi belajar meningkat menjadi 77,33 Ketuntasan belajar juga terjadi peningkatan sehingga mencapai $73,68 \%$. Pada Siklus II rata-rata prestasi belajar mencapai rata-rata 79,62 dan ketuntasan belajar 89,47 $\%$. Kesimpulan yang diperoleh dari penelitian ini adalah Penerapan Model Pembelajaran Inkuiri Terbimbing dapat meningkatkan prestasi belajar IPA siswa pada kelas IX-7 SMP Negeri 2 Singaraja smester ganjil tahun pelajaran 2017/2018
\end{abstract}

A B S T R A C T

The purpose of this class action research is to increase the activities and student achievement in science learning through the Application of a Guided Inquiry Learning Model. The research data was collected through observation of student activities in the learning process and learning achievement tests, which were then analyzed using qualitative descriptive methods for data on student activities in the learning process, as well as quantitative descriptive data for the test of learning achievement. Data is presented in the form of averages and completeness learning process. The application of the Guided Inquiry learning model can positively change the quality of science learning, evidenced by the development of learning achievement. At first the average student learning achievement was only 72.48 with learning completeness of only $44.74 \%$, then after the implementation of Cycle I the average learning achievement increased to 77.33 Study mastery also increased to reach $73.68 \%$. In Cycle II the average learning achievement reached an average of 79.62 and learning completeness was $89.47 \%$. The conclusions obtained from this study are the Application of Guided Inquiry Learning Model can improve students' science learning achievement in class IX-7 Singaraja Public Middle School 2 odd semester of the academic year 2017/2018. 


\section{Pendahuluan}

Pembelajaran IPA terpadu memiliki karakteristik bahwa pembelajaran berpusat pada peserta didik, menekankan pembentukan pemahaman dan kebermaknaan, belajar melalui pengalaman langsung, lebih memperhatikan proses daripada hasil belajar, dan sarat dengan muatan keterkaitan. Pembelajaran terpadu dikatakan berpusat pada peserta didik karena pembelajaran terpadu merupakan suatu sistem pembelajaran yang memberikan keleluasaan kepada peserta didik untuk bereksplorasi. Peserta didik aktif mencari, menggali, dan menemukan konsep serta prinsip pengetahuan yang harus diketahui sesuai dengan perkembangnnya.

Pembelajaran menekankan kepada pembentukan pemahaman dan Kebermaknaan (Bermakna) Pembelajaran terpadu mengkaji suatu fenomena dari berbagai aspek yang membentuk semacam jalinan antarskemata yang dimiliki peserta didik sehingga berdampak pada kebermaknaan materi yang dupelajari peserta didik. Peserta didik memperoleh hasil yang nyata tentang konsep yang diperoleh serta keterkaitannya dengan konsep lain yang dipelajari.

Pembelajaran IPA terpadu merupakan salah satu model implementasi kurikulum yang dianjurkan untuk diaplikasikan di jenjang pendidikan dasar yaitu SD dan SMP. Pelaksanaan pembelajaran IPA terpadu membutuhkan profesionalisme guru yang memadai. Guru harus memiliki cukup ilmu dalam menyampaikan pengetahuan IPA secara utuh. Selain itu, dalam penyampaian IPA secara terpadu diperlukan suatu sarana yang berupa model pembelajaran beserta perangkat pembelajaran yang sesuai (Rahayu, 2012).

Terkait dengan hal tersebut, maka dalam belajar IPA seorang guru harus mampu mengupayakan untuk menanamkan konsep-konsep yang tertuang pada setiap pokok bahasan yang ada kepada siswa sebagai sebuah proses dalam belajar. Bruner (Suherman, 2003: 43) mengatakan, belajar IPA akan lebih berhasil jika proses pengajaran diarahkan kepada konsep-konsep dan struktur-struktur yang termuat dalam pokok bahasan yang diajarkan serta anak sebaiknya diberi kesempatan untuk memanipulasi benda-benda (alat peraga) serta dalam proses belajar anak melewati 3 tahap yaitu; Tahap enaktif, dalam tahap ini anak secara langsung terlibat dalam memanipulasi objek. Tahap ikonik, dalam tahap ini kegiatan yang dilakukan anak berhubungan dengan mental, yang merupakan gambaran dari objek yang dimanipulasinya. Tahap simbolik, dalam tahap ini anak memanipulasi lambang atau simbol dari objek tertentu.

Pembelajaran di kelas akan berlangsung efektif serta dapat mencapai tujuan pendidikan yang dimaksud, apabila dikemas dengan strategi, metode dan pendekatan yang sesuai dengan pokok bahasan, juga guru memiliki keterampilan memilih media yang sesuai dengan karakteristik mata pelajaran serta peserta didik. Untuk itu guru semestinya memahami peran, fungsi dan kegunaan mata pelajaran yang diampu.

Pembelajaran IPA pada kelas IX-7 SMP Negeri 2 Singaraja, hasilnya belum memenuhi kriterria ketuntasan minimal (KKM). Berdasarkan penelitian awal yang dilaksanakan awal tahun pelajaran 2017/2018 (bulan Juli dan awal bulan Agustus 2017), memperoleh hasil berupa rata-rata nilai prestasi belajar siswa adalah; 72,48 dengan ketuntasan belajar 44,74\% artinya dari sejumlah 36 siswa kelas IX-7 ternyata yang berhasil mencapai KKM (tuntas) baru 17 orang, dengan KKM 75. Dari refleksi terhadap kondisi ini ditemukan penyebabnya adalah;(1) Kebiasaan-kebiasaan guru mengajar tanpa membuat persiapan yang baik, (2) proses pembelajaran masih berpusat pada siswa, (3) beberapa konsep materi IPA sulit untuk dipahami, (4) respon siswa terhadap mata pelajaran IPA sangat rendah, mereka memandang bahwa IPA adalah mata pelajaran yang sulit untuk dipahami sehingga siswa seringkali putus asa jika mengalami permasalahan pembelajaran. Untuk menanggulangi permasalahan ini guru IPA mestinya menguasai keterampilan mengelola kelas yang dapat melibatkan siswa dalam pembelajaran berupa; 1) keterampilan bertanya, 2) keterampilan memberi penguatan, 3) keterampilan mengadakan variasi, 4) keterampilan menjelaskan, 5) keterampilan membuka dan menutup pelajaran, 6) keterampilan membimbing diskusi, 7) keterampilan mengelola kelas. Keterampilan-keterampilan ini berhubung dengan kemampuan guru untuk menguasai dasar-dasar pengetahuan yang berhubungan dengan persiapan dan pelaksanaan proses pembelajaran yang akan memberikan dukungan terhadap cara berpikir siswa yang kreatif dan imajinatif. Hal inilah yang menunjukkan profesionalisme guru (I G. A. K. Wardani dan Siti Julaeha, Modul IDIK 4307: 1-30).

Dari semua uraian tersebut, dapat diketahui hal-hal yang perlu dalam upaya meningkatkan prestasi belajar siswa seperti penguasaan metode-metode ajar; penguasaan model-model pembelajaran; penguasaan teori-teori belajar; penguasaan teknik-teknik tertentu; penguasaan peran, fungsi serta kegunaan mata pelajaran. Apabila betul-betul guru menguasai dan mengerti tentang hal-hal tersebut dapat diyakini bahwa prestasi belajar peserta didik pada mata pelajaran IPA tidak akan rendah. Namun 
kenyataannya prestasi belajar IPA siswa kelas IX-7 di semester ganjil tahun ajaran 2017/2018 baru mencapai mencapai rata-rata seperti tersebut.

Melihat kesenjangan antara harapan-harapan yang telah disampaikan dengan kenyataan lapangan sangat jauh berbeda, agar masalah ini tidak berlarut-larut dan segera dapat dipecahkan dalam upaya memperbaiki mutu pendidikan, sangat perlu kiranya dilakukan perbaikan metode pembelajaran. Salah satunya adalah perbaikan pembelajaran dengan menggunakan strategi pembelajaran Inquiri terbimbing. Hal ini dicobakan mengingat masalah yang diteliti merupakan suatu masalah penting dan mendesak untuk dipecahkan.

Rumusan penelitian ini adalah; Apakah penerapam model pembelajaran Inquiri Terbimbing dapat meningkatkan prestasi belajar IPA siswa kelas IX-7 SMP Negeri 2 Singaraja pada semester ganjil tahun pelajaran 2017/2018? Tujuan penelitian ini adalah untuk meningkatkan prestasi belajar IPA siswa kelas IX-7 SMP Negeri 2 Singaraja semester ganjil tahun pelajaran 2017/2018 setelah mengikuti pembelajaran IPA dengan menggunakan model pembelajaran Inquiri Terbimbing. Penelitian ini diharapkan bermanfaat Bagi siswa, penelitian ini bermanfaat untuk meningkatkan kualitas pembelajaran sehingga, sehingga KKM dapat tercapai, bagi Guru mata pelajaran IPA, bermanfaat untuk dapat meningkatkan kompetensi guru dalam mengatasi masalah pembelajaran di kelas. Bagi guru mata pelajaran secara umum, Bermanfaat untuk peningkatan sikap profesionalisme guru, yang akan membantu terjadinya perbaikan pembelajaran serta peningkatan proses pembelajaran di kelas. Bagi sekolah, memperkaya model dan strategi pembelajaran dalam praktiknya untuk meningkatkan kualitas output sekolah.

\section{Metode}

Penelitian yang dilakukan termasuk penelitian tindakan yang pada intinya bertujuan untuk memperbaiki berbagai persoalan nyata dan praktis dalam peningkatan mutu pembelajaran di kelas, yang dialami langsung dalam interaksi antara guru dengan siswa yang sedang belajar (Suhardjono, Suparno, Supardi, Abdul Azis Hoesein, 2009: 39). Rancangan penelitian tindakan yang digunakan adalah rangcangan penelitian menurut Depdiknas Subjek penelitian ini adalah semua siswa kelas IX-7 SMP Negeri 2 Singaraja. Alasan dipilihnya kelas ini sebagai objek penelitian adalah karena permasalahan penelitian ini muncul di kelas ini. Yang menjadi objek penelitian ini adalah peningkatan prestasi belajar siswa dalam pembelajaran IPA. Penelitian ini dilakukan selama 3 bulan yakni; dari bulan Agustus 2017 sampai bulan oktober 2017.

Metode pengumpulan data penelitian ini digunakan tes prestasi belajar, dengan pelaksanaannya setiap akhir pertemuan melalui posttest. Test prestasi yang digunakan adalah sesuai dengan instrumen yang telah disusun pada RPP. Metode yang digunakan untuk menganalisis data hasil penelitian ini adalah metode deskriptif kuantitatif, dengan memberi komentar-komentar mengklasifikasikan data, dan selanjutnya membuat kesimpulan refleksi dengan mencari makna dari kesimpulan hubungan antar kategori. Dalam penelitian ini, tingkat keberhasilan dikur dari rata-rata prestasi belajar siswa yakni bila secara individu telah mencapai sama dengan atau melebihi KKM yakni 75, dan secara klasikal rata-rata ketuntasan belajar telah melebihi $85 \%$.

\section{Hasil dan Pembahasan}

Pelaksanaan penelitian siklus I diawali dengan perencanaan, yakni (1) menulis kekurangankekurangan yang terjadi sebelumnya, (2) menyusun jadwal, (3) mengidentifikasi masalah/fokus peristiwa yang akan diamati, (4) merencanakan cara yang akan dilakukan, (5) berkonsultasi dengan teman sejawat, (6) membuat rumusan masalah yang jelas, (7) memutuskan pokok bahasan yang akan diajar, (8) mendiagnosis masalah yang ada, bahwa masalah ini adalah startegi pembelajaran harus diubah dengan mengimplementasikan model pembelajaran Inkuiri Terbimbing. Perencanaan yang dilaksanakan terkait implementasi model pembelajaran dimaksud adalah;

Sesuai jadwal pelajaran, maka pelaksanaan pembelajaran IPA dengan mengimplementasikan model pembelajaran Inkuiri Terbimbing dilaksanakan di kelas IX-7. Pelaksanaan pembelajaran mengikuti standar proses pembelajaran, yang terdiri dari tiga tahapan kegiatan yakni; tahap pembukaan, tahap kegiatan inti dan tahap kegiatan penutup. Pada kegiatan pembukaan dilaksanakan melalui (1) mengucapkan salam, (2) doa bersama sebelum kegiatan pembelajaran dimulai, (3) mengingatkan materi yang lalu melalui pertanyaan-pertanyaan dan mempersilahkan pada siswa untuk menyampaikan hasil tugas yang diberikan pada minggu sebelumnya, (4) menyampaikan KKM yang harus dicapai siswa, (5) mengaitkan antara materi sebelumnya dengan materi yang akan diajarkan, (6) menyampaikan materi yang akan diajarkan pada pertemuan kali ini. 
Terkait dengan implementasi model pembelajaran Inkuiri Terbimbing maka tahapan proses pembelajaran IPA dilaksanakan dengan tahapan atau sintaks kegiatan meliputi ;(a) Tahap berhadapan dengan masalah. Pada kegiatan ini, siswa diberikan pertanyaan atau permasalahan yang disusun sedemikian rupa sehingga tidak mengakibatkan guru memberikan jawaban dari pertanyaan tersebut, melainkan mengarahkan atau membimbing siswa unruk menemukan jawabannya sendiri. Siswa dilatih untuk dapat memahami masalah. (b) Pengumpulan informasi. Setelah memahami masalah yang diberikan, siswa mengumpulkan informasi tentang masalah yang dihadapi selanjutnya dirumuskan untuk pemecahan masalah yang diberikan. (c) Pengumpulan data. Data atau informasi yang telah diperoleh pada tahap sebelumnya kemudian digunakan sebagai acuan untuk menentukan jawaban dari permasalahan yang telah diberikan. (d) Selanjutnya siswa melakukan diskusi untuk menganalisis dan menyelidiki permasalahan guna mendapatkan pemecahan masalah serta jawaban dari masalah yang telah diberikan. (e) Hasil diskusi tersebut kemudian dipresentasikan di depan kelas, siswa yang lain diberikan kesempatan untuk bertanya, menyampaikan pendapat atau masukan. (f) Analisis proses inkuiri. Pada tahap ini siswa dibimbing untuk menganalisis hasil diskusi mengenai permasalahan yang diberikan, kemudian menarik suatu kesimpulan terhadap kegiatan yang telah dilakukan.

Pelaksanaan observasi dilakukan dalam upaya untuk mengetahui kesesuaian antara sintak perencanaan pembelajaran dengan pelaksanaan, mengetahui efektivitas waktu, kegiatan dan proses pelaksanaan, dan tes prestasi belajar dalam upaya untuk mengumpulkan data tentang efek implementasi model pembelajaran Inkuiri Terbimbing terhadap prestasi belajar siswa, serta sebagai bahan dalam membandingkan antara data hasil yang diperoleh dengan indikator keberhasilan penelitian. Observasi dilaksanakan bersamaan dengan pelaksanaan pembelajaran dengan menggunakan teman sejawat guru IPA sebagai observernya.

Tahap refleksi, menemukan analisis kuantitatif prestasi belajar siswa siklus I, meliputi, rata-rata (mean) yang diperoleh adalah; 77,33 ketuntasan belajar 73,68 \%. Sintesis terhadap pelaksanaan siklus I, adalah menyangkut Keberhasilan yang diperoleh siswa dengan menunjukkan hasil rata-rata 72,48 ketuntasan belajar 44,74\%, hal ini menunjukkan bahwa dari 38 orang siswa subjek penelitian terdapat 28 orang siswa telah berhasil memperoleh nilai rata-rata diatas KKM (75) dan sebanyak 10 orang siswa yang belum mampu mencapai KKM/ nilai rata-rata yang diperoleh dibawah KKM, sehinga mereka perlu dibina kembali. Peningkatan prestasi belajar dari data awal tidak terlepas dari perencanaan, pelaksanaan dan observasi yang telah dilaksanakan. Perencanaan yang dimulai dengan menyusun RPP yang baik dan benar sesuai alur inquiri terbimbing dengan melihat kekurangan yang ada sebelumnya, yaitu pembelajaran masih dilakukan secara konvensional, belum ada upaya konstruktivisme dan inkuiri, belum mampu merumuskan tujuan yang tepat, materi belum berhubungan dengan indikator.

Penilaian terhadap keberhasilan PTK dapat diuraikan sebagai berikut; (1) Perencanaan siklus I sudah dilaksanakan secara matang, dengan membuat RPP sesuai alur inquiri terbimbing lebih menuntun siswa mampu meningkatkan kemampuan belajarnya. (2) Pada tahap pelaksanaan, peneliti telah mengupayakan agar alur inquiri terbimbing berjalan sesuai harapan sehingga siswa betul-betul belajar sesuai harapan model pembelajaran ini. (3) Pengamatan/observasi juga sudah berjalan sesuai harapan. (4) pelaksanaan refleksi terhadap hasil penelitian siklus I telah dilaksanakan dengan baik, dan penilaian terhadap hasil penelitian siklus I ini jika dikonfirmasi dengan indikator keberhasilan penelitian ternyata penelitian ini belum dapat diketegorikan berhasil, karena pada bagian sebelumnya telah disampaikan indikator keberhasilan penelitian ini adalah jika nilai rata-rata prestasi belajar siswa telah mencapai minimal sama atau lebih dari KKM yang telah ditentukan, dan telah mencapai ketuntasan klasikal sebanyak 85. KKM yang ditentukan adalah 75, sedangkan rata-rata prestasi belajar siswa yang diperoleh pada siklus I ini baru mencapai 77,33 dan ketuntasan klasikal baru mencapai 73,68\% Dengan demikian maka pelaksanaan penelitian dilanjutka pada siklus II. Walaupun hasilnya belum memenuhi kriteria keberhasilan, namun pelaksanaan penelitian siklus I ini perlu dinilai keunggulan maupun kelemahannya. Berikut ini disampaikan keunggulan dan kelemahan siklus I ini.

Keunggulan-keunggulan yang telah nampak dari pelaksanaan siklus I ini jika dibandingkan dngan proses pembelajaran sebelumnya adalah; Siswa telah menguasai ketrampilan dan proses kognitif dalam memecahkan permasalahan yang diberikan, Siswa mulai terbiasa kerja secara kelompok dan mampu menyajikan hasil diskusi atau kerja kelompoknya, Gairah belajar pada siswa mulai meningkat, dapat dilihat dari persensi atau kehadiran siswa serta kemauan melaksanakan tugas-tugas yang dibebankan kepadanya, Guru betul-betul sebagai teman belajar bagi siswa, dan siswa telah berani secara terbuka bertanya tentang permasalahan atau materi lainnya,

Kendala yang masih ada adalah beberapa siswa masih terpaku kepada pola pembelajaran lama, masih tercengang memikirkan kebiasaan yang lama dimana mereka masih senang untuk dijarkan materi pelajaran oleh gurunya, beberapa siswa belum terbiasa bertanya, berdiskusi, mengerjakan tugas-tugas atau memecahkan permasalahan, mempresentasikan hasil kerja kelompoknya. Disisi lain guru terkendala 
dalam merubah kebiasaan untuk tidak mengajarkan kepada siswa, tetapi melaksanakan kegiatan membelajarkan siswa sehingga kegiatan menceramahkan materi harus dikurangi. Untuk menanggulangi kendala-kendala ini, pada siklus II guru lebih fokus kepada pembimbingan serta memotivasi munculnya segala bentuk aktivitas siswa melalui memberikan rangsangan-rangsangan berupa reward dan funihsment. Sedangkan kendala yang masih dihadapi oleh guru adalah diupayakan melalui pembiasaan dalam proses pembelajaran selalu memperhatikan tahapan-tahapan kegiatan pembelajaran sesuai model yang digunakan.

Dengan melihat semua hasil penelitian yang dicapai pada siklus I, baik refleksi data kualitatif maupun refleksi data kuantitatif, maka dilaksanakan perencanaan ulang untuk pelaksanaan penelitian di siklus II. Pada hari yang sudah ditentukan sesuai jadwal, peneliti memulai tahap pelaksanaan tindakan dengan membawa semua persiapan yang sudah dibuat. Implementasi model pembelajaran Inkuiri Terbimbing sesuai dengn sintaks nya dengan menanggulangi hal-hal yang masih menjadi kelemahankelemahan sehingga hasil pada siklus seelunya belum maksimal. Hal ini dimaksudkan agar implementasi model ini pada siklus II dapat memperoleh hasil sesuai dengan harapan.

Seperti halnya pelaksanaan siklus sebelumnya, pelaksanaan pembelajaran siklus II ini juga mengikuti standar proses pembelajaran, yang terdiri dari tiga tahapan kegiatan yakni; tahap pembukaan, tahap kegiatan inti dan tahap kegiatan penutup. Pada kegiatan pembukaan dilaksanakan melalui (1) mengucapkan salam, (2) doa bersama sebelum kegiatan pembelajaran dimulai, (3) mengingatkan materi yang lalu melalui pertanyaan-pertanyaan dan mempersilahkan pada siswa untuk menyampaikan hasil tugas yang diberikan pada minggu sebelumnya, (4) menyampaikan KKM yang harus dicapai siswa, (5) mengaitkan antara materi sebelumnya dengan materi yang akan diajarkan, (6) menyampaikan materi yang akan diajarkan pada pertemuan kali ini, (7) standar kompetensi yang harus dikuasai siswa.

Observasi dilaksanakan dengan mencatat semua kegiatan yang terjadi, semua reaksi yang sudah dilakukan, menggunakan lembar observasi dalam upaya untuk mengetahui kesesuaian antara sintak perencanaan pembelajaran dengan pelaksanaan, mengetahui efektivitas waktu, kegiatan dan proses pelaksanaan, dan tes prestasi belajar dalam upaya untuk mengumpulkan data tentang efek implementasi model pembelajaran Inkuiri Terbimbing terhadap prestasi belajar siswa, serta sebagai bahan dalam membandingkan antara data hasil yang diperoleh dengan indikator keberhasilan penelitian.

Analisis kuantitatif dilaksanakan untuk perolehan Prestasi Belajar Siklus II. Dari hasil tersebut diperoleh Rata-rata (mean) hasil tes prestasi belajar siswa adalah 79,62 ketuntasan belajar klasikalnya adalah 89,47 \%. Nilai rata-rata yang diperoleh pada siklus II menunjukkan peningkatan. Pada siklus I, rata-rata prestasi belajar siswa 77,33 sedangkan pada siklus II menjadi 79,62 terjadi peningkatan sebanyak 2,3. Jika dilihat dari ketuntasan klasikal juga terjadi peningkatan yakni dari 73,68\% pada siklus I menjadi 89,47 \% pada siklus II, terjadi peningkatan sebanyak 15,80\%. Dari sejumlah 38 orang subjek penelitian ini ditemukan 34 orang siswa yang sudah mampu memperoleh nilai rata-rata prestasi belajar diatas KKM (75), sebanyak 4 orang siswa memperoleh nilai rata-rata prestasi belajar dibawah KKM (75). Siswa yang memperoleh nilai di bawah rata-rata akhirnya dibina kembali, diberi arahan-arahan, motivasimotivasi, penguatan-penguatan agar mereka berupaya lebih baik. Secara keseluruhan hasil yang didapat telah memenuhi kriteria keberhasilan penelitian sehingga tidak diteruskan lagi ke siklus berikutnya.

Setelah dibandingkan nilai awal, nilai siklus I dan nilai siklus II, terjadi kenaikan. Kenaikan ini tidak bisa dipandang sebelah mata karena kenaikan nilai ini adalah dari upaya-upaya yang maksimal yang dilaksanakan peneliti demi peningkatan mutu pendidikan dan kemajuan pendidikan khususnya di SMP Negeri 2 Singaraja. Keberhasilan implementasi model pembelajaran inkuiri terbimbing tidak lepas dari keunggulan model dimaksud. Suryobroto (2002: 201) menyebutkan kelebihan inkuiri terbimbing (guide inquiry) antara lain. (a) Membantu siswa dalam mengembangkan atau memperbanyak persediaan dan penguasaan ketrampilan dan proses kognitif siswa. (b) Membangkitkan gairah pada siswa, misalkan siswa merasakan jerih payah penyelidikannya, menemukan keberhasilan dan kadang-kadang kegagalan. (c) Memberi kesempatan pada siswa untuk bergerak maju sesuai dengan kemampuan. (d) Membantu memperkuat pribadi siswa dengan bertambahnya kepercayaan pada diri sendiri melalui proses-proses penemuan. (e)Model ini berpusat pada anak, misalkan memberi kesempatan kepada mereka, dan guru berpartisipasi sebagai teman belajar dalam mengecek ide. (f)Guru menjadi teman belajar, terutama dalam situasi penemuan yang jawabanya belum diketahui.

\section{Simpulan Dan Saran}

Berdasarkan pada semua data yang telah disampaikan tersebut, maka simpulan penelitian ini adalah bahwa penerapam model pembelajaran Inquiri Terbimbing dapat meningkatkan prestasi belajar IPA siswa kelas IX-7 SMP Negeri 2 Singaraja pada semester ganjil tahun pelajaran 2017/2018. 
Berdasarkan temuan yang sudah disimpulan dari hasil penelitian, dalam upaya mencapai tujuan pembelajaran IPA, dapat disampaikan saran-saran sebagai berikut: (1) Dalam melaksanakan proses pembelajaran pada mata pelajaran IPA, penggunaan model Inkuiri Terbimbing semestinya menjadi pilihan dari beberapa metode yang ada mengingat metode ini telah terbukti dapat meningkatkan kerjasama, berkreasi, bertindak aktif, bertukar informasi, mengeluarkan pendapat, bertanya, berdiskusi, berargumentasi dan lain-lain. (2) Walaupun penelitian ini sudah dapat membuktikan efek utama dari model Inkuiri Terbimbing dalam meningkatkan prestasi belajar, sudah pasti dalam penelitian ini masih ada hal-hal yang belum sempurna dilakukan, oleh karenanya kepada peneliti lain yang berminat meneliti topik yang sama untuk meneliti bagian-bagian yang tidak sempat diteliti. (3)Selanjutnya untuk adanya penguatan-penguatan, diharapkan bagi peneliti lain untuk melakukan penelitian lanjutan guna verifikasi data hasil penelitian.

\section{Daftar Rujukan}

Ambarsari, W., Santosa, S. and Maridi, M., 2013. Penerapan pembelajaran inkuiri terbimbing terhadap keterampilan proses sains dasar pada pelajaran biologi siswa kelas VIII SMP Negeri 7 Surakarta. Jurnal Pendidikan Biologi, 5(1), pp.81-95.

Arikunto, Suharsimi; Suhardjono; Supardi. 2006. Penelitian Tindakan Kelas. Jakarta: PT Bumi Aksara.

Direktorat Tenaga Kependidikan, Direktorat Jendral Peningkatan Mutu Pendidik dan Tenaga Kependidikan. 2008. Metode dan Teknik Supervisi. Jakarta: Depdiknas.

Dimyati dan Mudjiono. 2001. Belajar dan Pembelajaran. Jakarta: Dirjen Dikti.

Djamarah, Syaful Bahri. 2002. Prestasi Belajar dan Kompetensi Guru. Surabaya: Usaha Nasional.

Dahar, Ratna Wilis. 1989. Teori-Teori Belajar. Jakarta: Penerbit Erlangga.

Muhlisin, A., 2012. Pengembangan Perangkat Pembelajaran IPA Terpadu Berbasis Contextual Teaching and Learning (CTL) dengan Model Pembelajaran Kooperatif Tipe Student Teams Achievement Division (STAD) Tema Polusi Udara. Journal of Educational Research and Evaluation, 1(2).

Purwanto, D., 2013. Pengembangan Media Komik Ipa Terpadu Tema Pencemaran Air Sebagai Media Pembelajaran Untuk Siswa SMP Kelas VII. PENDIDIKAN SAINS, 1(01).

Rahayu, P., Mulyani, S. and Miswadi, S.S., 2012. Pengembangan pembelajaran ipa terpadu Dengan menggunakan model pembelajaran problem base melalui lesson study. Jurnal Pendidikan IPA Indonesia, 1(1).

Supardi, 2005. Pengembangan Profesi dan Ruang Lingkup Karya Ilmiah. Jakarta: Depdiknas.

Slameto. 2000. Belajar dan Faktor-Faktor yang Mempengaruhinya. Jakarta: Rineka Cipta.

Slavin, Robert E. 1995. Cooperative Learning : Theory, Research, and Practice. Boston: Allyn and Bacon.

Wardani, I. G. A. K Siti Julaeha. Modul IDIK 4307. Pemantapan Kemampuan Mengajar. Jakarta: Universitas Terbuka.

Widiyatmoko, A., 2013. Pengembangan perangkat pembelajaran IPA terpadu berkarakter menggunakan pendekatan humanistik berbantu alat peraga murah. Jurnal Pendidikan IPA Indonesia, 2(1).

Woolfolk, Anita E. 1993. Educational Psychology. Fifth Edition. Boston: Allyn and Bacon. 